\title{
Rivalry in medicine and the wine business
}

\author{
Shaun R. McCann $\mathbb{1 0}^{1}$
}

Received: 15 February 2021 / Revised: 20 February 2021 / Accepted: 2 March 2021 / Published online: 25 March 2021

(c) The Author(s), under exclusive licence to Springer Nature Limited 2021

\begin{abstract}
'Do nothing out of rivalry or conceit, but in humility consider others as more important than your selves. Everyone should look at not only for his/her own interests, but also for the interests of others'.
\end{abstract}

\section{Phillipians 2: 3-4}

Pauline epistle of the New Testament.

It seems that rivalry is one of the oldest emotions known to man and the Greek Gods. Kronos, King of the Titans, and god of time, begat a number of children, including Zeus. Kronos, Fig. 1. It was foretold that he would be deposed by one of his sons. In order to prevent this, he devoured his children. To avoid this fate, Zeus, was hidden in a cave and nurtured by animals. However, Zeus eventually dethroned Kronos and became the father of Dionysus, god of wine.

Many people believe that some degree of rivalry/competition is a good thing but few, if any, would condone eating one's children. Of course, competition can be helpful but can also be destructive. One of the two most widely known rivalries in medicine, was between the English and the French in the development of blood transfusion in the 17th century. The two names that stand out are JeanBaptiste Denys (French) and Richard Lower (English) Fig. 2. The Royal Society in England was founded shortly before the French Academy of Science, which may have compounded the rivalry between these two outstanding doctors/scientists [1]. Lower and his colleagues were primarily interested in perfecting the technique of blood transfusion and trying to answer the question: 'Did blood contain memory, the soul and other human attributes'? [1]. Blood transfusions from animals to man were practiced in

Shaun R. McCann

shaunrmccann@gmail.com

1 University of Dublin Trinity College, Haematology Emeritus, Dublin, Ireland both jurisdictions, but fell into disrepute when Denys transfused blood from a calf into a human, resulting in a fatal haemolytic transfusion reaction. Following this, the French Parliament deemed transfusion a criminal act and the Royal Society soon followed suit. Pope Innocent X1 (1629-1691) also banned the practice in 1679. Nobody seems to have asked if blood transfusion could save the lives of bleeding patients. It was to be another 250 years before this therapeutic intervention became common practice. Even though many of us take blood transfusion for granted, a sect, Jehovah witnesses, forbids transfusion, which incidentally does not preclude haematopoietic cell transplantation or surgery [2].

One of the least attractive examples of rivalry in recent/ contemporary medicine was the 'race' to find the cause of HIV (AIDS). This time the French were pitted against the Americans. A French victory finally ensued with the Nobel Prize awarded in 2008, to the French virologists, Luc Antoine Montagnier and Françoise Barré-Sinousssi.

An egregious example of rivalry/fraud in medicine was the claim of Haruko Obokata in South Korea. This related to the production of pluripotent stem cells in 2006 [3]. Remarkably, the fraudulent results were published in a reputable peer-reviewed medical journal.

Of course, rivalry is not confined to medicine and the well-known rivalry between France and England, once again, became contentious during the Napoleonic attempt to conquer Egypt and his defeat by Nelson at the "battle of the Nile'. Although French philologist (1790-1832), JeanFrançois Champollion, deciphered the hieroglyphs of the 'Rosetta Stone' Fig. 3, enabling our understanding of ancient Egypt and pharaonic civilization, ironically, the 'Rosetta Stone' was captured as war booty and is now in the British Museum in London [3].

Does rivalry occur in the wine trade? Of course, it does. Any business that requires a large investment of time and money and depends on the sale of the final product, is bound to induce rivalry. Šperková and Hegmalová [4], in a detailed study of wine rivalry in the Czech Republic, pointed out that intense rivalry was most prominent in wine 


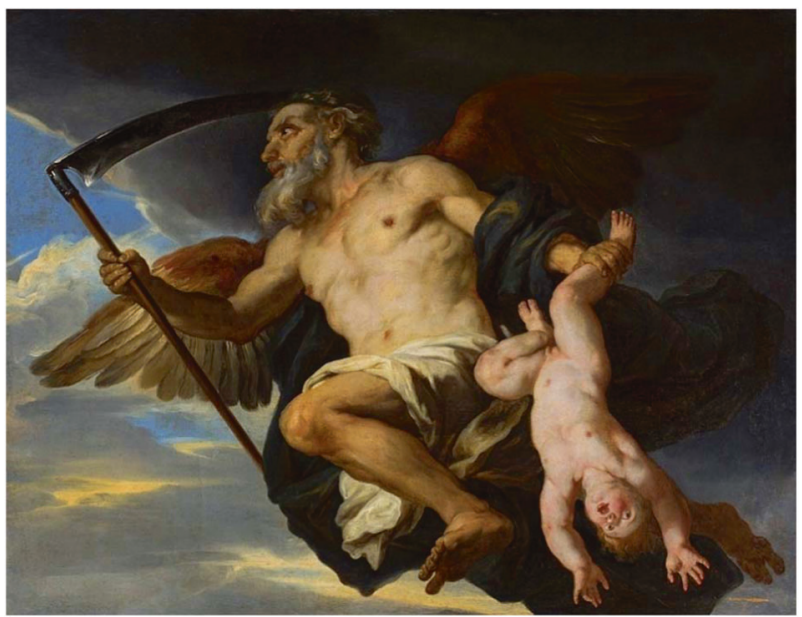

Fig. 1 Kronos. Kronos, the god of time, and his child. Oil on canvas, National Museum of Warsaw. Giovanni Francesco Romanelli (1610-1662).



Fig. 2 Sir Richard Lower. Richard Lower a physician, remembered for his work on blood transfusion.

makers who had the largest market share. They claimed that the main reason for this rivalry was to obtain the best position for wine distribution, mainly to chain stores. There is absolutely no reason to doubt that the same rivalries exist in France, Italy [5], Spain or the USA.

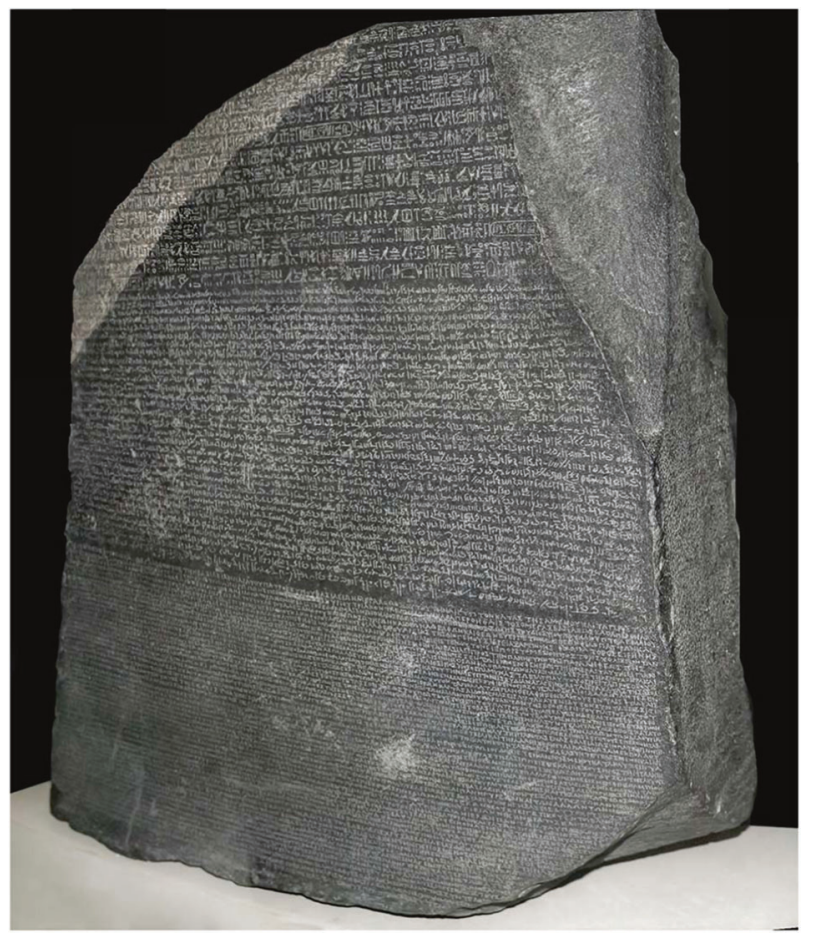

Fig. 3 The Rosetta Stone. The Rosetta Stone was 'discovered' in Egypt and deciphered by Jean François Champollion.

The bad news is that wine sales are decreasing internationally and this, no doubt, increases the chance of rivalry. Health consciousness, the absence of liquid lunches, and the abundance of non-alcoholic beverages from which to choose are undoubtedly contributary factors. France has been the major fine wine producer for many years, but the 'blind tasting' of Californian wines, compared to French wines, in 1976, organized by Steven Spurrier [6], stopped the French in their tracks. Since then, Italian and Spanish wines have improved in quality and many other countries have entered the international market including South Africa, South America, Austria, Germany (which probably always suffered because of the difficulty in reading their labels), New Zealand, Hungary and Eastern Europe, Greece and Turkey. England is also about to become a major player in the sparkling wine trade. Other States, besides California, are now producing top quality wines. I have tasted good wines from India and although China is now a major wine producer, I have not had the opportunity to taste any of their wines.

Australian wines 'came of age' in the 1970s, when Len Evans introduced them to the UK. Of course, Australian wine had to fight prejudice, and Hazel Murphy was a major player in conquering the international market. A sociological change took place in the 1970s; women began to drink wine and the 'package holiday' was inaugurated which introduced many people to wine for the first time. Brian Avery devised a clever marketing strategy when he 
arranged a tour of Australian vineyards for a group of Masters of Wine (MWs) and sent a bottle of Rosemount Chardonnay to each of their wives (MWs were all male).

In the USA, wine consumption is decreasing among aging baby boomers (those born between 1946 and 1964), millennials (those born between 1980s and 1990s), purportedly because of a decrease in income and the wide availability of cannabis! What sounds like a ghastly concoction, in a can, called 'hard selzer' (sparkling water, alcohol, usually fermented cane sugar and fruit flavouring) has also contributed to the decline. However, spending on wine has remained steady, as more people are drinking more expensive wines. Somewhat surprisingly, sales of Rosé are increasing in the USA and decreasing in France.

A sequela of the recent Covid-19 pandemic is that it has hurt wine sales because of the closure of restaurants, and the tariffs on French wine in the USA, and Australian wine in China. Judith Evans and Peter Foster, writing in the weekend FT on January 23/24, predict an increase in the cost of a bottle of wine in the UK of $£ 1.50$ (\$2.0, €1.7), due to post-Brexit increases in custom declarations and higher haulage prices. They also predict a reduction in the selection of wines being imported. How this will affect wine consumption remains to be seen.

Happily, the development of vaccines against Covid-19 seems to represent cooperation rather than rivalry among scientists. Without sounding too cynical, however, there are disturbing reports of rivalry in the acquisition of vaccine supplies by different countries. Data from the Global Health Innovation Center at Duke University, North Carolina, indicate a wide disparity of vaccine availability between high- and low-income countries, and a statement by the World Health Organisation (WHO) warning of a 'catastrophic moral failure', suggests that vaccine supply is unequal. Vaccine scandals and queue jumping are reportedly happening in many jurisdictions. Recent reports of 'vaccine tourism' and its attendant depletion of vaccines for locals are unseemly.
If you consider the current pandemic to be a 'battle' then the adage 'the first casualty in war is truth' may be apt. Although this phrase is commonly attributed to US Senator Hiram Johnson in 1918, apparently Samuel Johnson was there before him, and he in turn, was preceded by the Chinese general Sun Tzu in the $5^{\text {th }}$ century and Aeschylus, Greek playwright (525 - 456 BC).

As consumers/customers, we can sometimes benefit from rivalry between retailers, when a price war can mean bargains. But beware of unscrupulous retailers trying to dump poor quality wine on an unsuspecting public. A little knowledge will help so, try to find a trustworthy 'off license' or wine merchant. Try wines from 'New World' countries and don't be afraid to experiment. Get to know good and reliable vineyards, but remember, you are the final judge.

\section{Compliance with ethical standards}

Conflict of interest The author declares no competing interests.

Publisher's note Springer Nature remains neutral with regard to jurisdictional claims in published maps and institutional affiliations.

\section{References}

1. McCann SR. A History of Haematology: From Herodotus to HIV. Oxford Medical Histories. Oxford, UK: Oxford University Press; 2016.

2. Sloan JM, Ballen K. SCT in Jehovah's Witnesses: the bloodless transplant. Bone Marrow Transpl. 2008;41:837-44. https://doi.org/ 10.1038/bmt.2008.5

3. Wilkinson T. A world beneath the sands: adventures and archaeologists in the golden age of egyptology. London, UK: Picador; 2020.

4. Šperková R, Hegmalová H. Intensity of rivalry among existing competitors in the wine-making branch. Acta univ agric et Silv Mendel Brun Czech Repub. 2012;1X(2):429-36.

5. Crescimanno M, Galati A. Competitiveness of Italian wines in the international market. Bulg J Agric Sci. 2014;20:12-22.

6. McCann SR. The Judgement of Paris. Bone Marrow Transplant. 2018. https://doi.org/10.1038/s41409-018-0336-9 